\section{Intersections}

Canadian Journal of Music

Revue canadienne de musique
Intersections

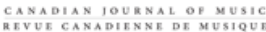

\title{
Alexander Scriabin's and Igor Stravinsky's Influence upon Early Twentieth-Century Finnish Music: The Octatonic Collection in the Music of Uuno Klami, Aarre Merikanto and Väinö Raitio
}

\section{Edward Jurkowski}

Volume 25, numéro 1-2, 2005

Northern Perspectives on Music and Culture

URI : https://id.erudit.org/iderudit/1013306ar

DOI : https://doi.org/10.7202/1013306ar

Aller au sommaire du numéro

Éditeur(s)

Canadian University Music Society / Société de musique des universités canadiennes

ISSN

1911-0146 (imprimé)

1918-512X (numérique)

Découvrir la revue

Citer cet article

Jurkowski, E. (2005). Alexander Scriabin's and Igor Stravinsky's Influence upon Early Twentieth-Century Finnish Music: The Octatonic Collection in the Music of Uuno Klami, Aarre Merikanto and Väinö Raitio. Intersections, 25(1-2), 67-85. https://doi.org/10.7202/1013306ar
Résumé de l'article

Cet article met en évidence une évolution importante du style musical et des techniques de composition apparus en Finlande au cours des années 1920, période pendant laquelle la musique de Jean Sibelius avait une grande influence. Plus précisément, mon propos porte sur les collections de type octatonique - particulièrement présentes chez les deux modernistes russes du début du XX ${ }^{\mathrm{e}}$ siècle, Igor Stravinsky et Alexandre Scriabine - et leur intégration à titre de ressource harmonique fondamentale dans trois œuvres pour orchestre reconnues: « la Création de la Terre », premier mouvement des cinq composant la Suite Kalevala de Uuno Klami (1935), le premier mouvement des 10 Pièces pour Orchestre de Aarre Merikanto (1924) et le poème orchestral Fantasia estatica de Väinö Raitio (1921).
Copyright (C Canadian University Music Society / Société de musique des universités canadiennes, 2005
Ce document est protégé par la loi sur le droit d'auteur. L'utilisation des services d'Érudit (y compris la reproduction) est assujettie à sa politique d'utilisation que vous pouvez consulter en ligne. 


\section{Alexander Scriabin's and Igor Stravinsky's Influence upon EARLy Twentieth-Century FinNish Music: The Octatonic Collection in the Music of Uuno Klami, Aarre Merikanto and Väinö Raitio}

\section{Edward Jurkowski}

\section{INTRODUCTION}

With the end of World War I and Finland's declaration of independence in 1917 , the country went through a number of seismic political and social changes. ${ }^{1}$ Not surprisingly, these substantial transformations to Finnish society were reflected in the visual arts, drama, literature, music, and architecture of this period. ${ }^{2}$ Many composers played a role in changing the prevailing style of music in Finland during the 1920s and 1930s, a style heavily influenced by the work of Jean Sibelius (1865-1957). Today, however, Uuno Klami (1900-61), Aarre Merikanto (1893-1958), Ernest Pingoud ${ }^{3}$ (1887-1942) and Väinö Raitio (1891-1945) are recognized as having made the most significant contributions during this period of strong stylistic evolution. In comparison to the ever-growing body of literature devoted to Sibelius, little scholarship and almost no analytical work has been devoted to the compositions of these four composers. This paper attempts to rectify this imbalance by illustrating an important shift away from the tertian-based harmonic language found in Sibelius's music. Specifically, I discuss how the octatonic collection, a prominent feature in the music of the two early twentieth-century Russian modernists, Igor Stravinsky and Alexander Scriabin, is incorporated as a fundamental harmonic resource in three celebrated orchestral works: Klami's 1935 "The Creation of the Earth," Merikanto's 1924 Ten Pieces for Orchestra, and Raitio's 1921 tone poem Fantasia estatica.

1 For discussion of the political changes found in Finland at this time see: Mead (1968), chapters six and seven from Singleton (1989), and Solsten and Meditz (1990, 16-41).

2 Jones (1985) contains a collection of essays that outline the influence that Finland's independence had upon painters and writers during the 1910s and 1920s, as regards the changing conception of the Kalevala.

3 Pingoud was born in St. Petersburg to a Russian-Finnish family. He emigrated to Finland in 1918 to escape the revolution and resided in Helsinki for the remainder of his life. However, because Pingoud's musical activities were based in Helsinki and played a prominent role with the change in musical style that took place during the 1910s and 1920s, he has been associated with these other important Finnish composers (i.e., Klami, Merikanto, and Raitio). 
Given the harmonic complexity of many works by these composers, it should be observed that the octatonic collection is not the sole harmonic resource that these composers utilized. In other words, the following article does not present an exhaustive accounting of the pitch language each composer developed in their works. Further, the comprehensive study of the use of the octatonic collection within each one of these compositions is beyond the scope of this article and remains the subject of a future series of papers. However, the pervasive appearance of the collection in these three particular works-and notably, as a resource that articulates the formal design of all three-is warranted to illustrate an important means of pitch organization that Finnish composers employed at that time. As such, these three compositions represent important exemplars of compositional thinking that appeared during this period of experimentation-i.e., one which challenged the norms of late-Romantic Finnish Nationalism, a style best exemplified by Sibelius.

\section{HISTORICAL CONTEXT}

Jean Sibelius is widely considered the first Finnish composer of international prominence and remains the country's most celebrated composer-arguably, even the most famous of any of the Nordic countries. His symphonies and symphonic poems represent essential contributions to large-scale orchestral music and have become highly valued objects of twentieth-century Finnish culture. However, despite the importance of Sibelius's music, both within Finland and abroad (particularly in England and the United States), ${ }^{4}$ Salmenhaara (1997) has noted that, ironically, Sibelius's influence upon younger Finnish composers was marginal after World War I. For instance, while the bold dissonant features of the Fourth Symphony of 1911 were heralded as a stylistic breakthrough, ${ }^{5}$ the clear tonal structures in Sibelius's works during the 1910s and 1920s (as, for instance, in the final three symphonies and the symphonic poems) were found to be regressive in nature and many simply refused to see the significance of his later output. ${ }^{6}$

This is not to say that Finnish composers during the 1910s and 1920s rejected Sibelius's work outright. For instance, composers such as Toivo

4 Gray (1996) contains a portrait of the exalted position that Sibelius's music held upon British composers and audiences between 1920 and 1960 .

5 The Finnish composer Einar Englund has recounted what impact the premiere of the Sibelius's Fourth Symphony had upon Merikanto and Raitio. His comments appear in Salmenhaara $(1997,176)$.

6 It is beyond the scope of this article to discuss the more advanced aspects of Sibelius's later compositions-for instance, issues of large-scale formal structure or long-range time spans. However, it should be acknowledged that these elements have been either ignored or placed on a lower level of importance when compared with more surface aspects of his music-for instance, triadic harmonies or nationalistic folk influences, features which critics, both Finnish and foreign, have used for decades as exemplars of a reactionary style of composition. In fact, it has only been in the past twenty years that Sibelius's music has begun to been viewed in a more positive manner. Some examples of the literature that discusses the more progressive features of Sibelius's music include: Hepokoski (1993), Howell (1989), Jackson and Murtomäki (2001), and Murtomäki (1993). For discussion about Sibelius's influence upon contemporary composers see Anderson (2004) and Szendy (1993, 11-12). Howell (1989) details some of the negative literature on Sibelius. 
Kuula (1883-1918), Leevi Madetoja (1887-1947) and Selim Palmgren (1878-1951) wrote music that occasionally integrated harmonic attributes of Claude Debussy's compositions with a sound world (as regards harmony, texture and formal design) influenced by Sibelius's pre-1910 works. ${ }^{7}$ However, as noted above, Klami, Merikanto, Pingoud and Raitio are the Finnish composers who have been generally recognized as generating the most pervasive change to the prevailing stylistic norms of Finnish music during the 1910 s and 1920s. These four founded no school and, to my knowledge, never collaborated together on any compositional project. Further, and perhaps not surprisingly, their stylistic and technical development followed divergent paths. Nevertheless, one can associate these composers because all four were attracted to the progressive music of Scriabin and Stravinsky (and to a lesser degree, to that of Debussy) that served as the basis for their radical music, rather than to the music of Richard Wagner, a particularly important foreign composer for Finns during the early twentieth century. ${ }^{8}$

To claim that the music of Merikanto, Pingoud and Raitio (and Klami during the 1920s) would have been controversial and poorly received by both audiences and critics can hardly be overstated. ${ }^{9}$ Simply put, while a new generation of Finnish composers was ready to embrace radical influences from outside Finland, they had to contend with an audience that placed Sibelius's music-and specifically, his overtly tonal and Kalevala-influenced compositions-on the highest level, a situation exacerbated by a country proud of the independence it had attained in $1917 .{ }^{10}$

The negative response that these four composers initially garnered has been attributed to the dissonant and unusual works they created, which were seen to be too far afield from the expected norms of the time. ${ }^{11}$ While this traditional perspective is not incorrect, the picture is complicated by cultural and political factors. For example, one could argue that the minimal use of the Kalevala for programmatic themes in Merikanto's, Pingoud's and Raitio's music, at a time

7 Nummi $(1985,34-50)$ discusses the role French music had in the music of Kuula, Madetoja and Palmgren. Tyrväinen (2000) discusses the role Debussy had upon early twentieth-century Finnish concert life.

8 Chapter two from Henshall (1984) discusses the role Wagner played upon late nineteenth-and early twentieth-century Finnish composers.

9 For discussion regarding the critical reaction to these Finnish composers during the 1910s and 1920s, see chapter five from Korhonen (2003) and Oramo (2004).

10 The Kalevala is an epic collected and assembled by the Finn Elias Lönnrot and published in 1835. It represents an important source of icons for Finnish culture and is Finland's most significant contribution to world literature. The success of the epic poem served as a catalyst for a series of important nineteenth-century novelists and poets, and for the first time in the country's history aspects of everyday Finnish society were celebrated in a literary context utilizing the Finn's own language. Even more important, however, is that the elevation of Finnish as a vital component of its culture became inextricably associated with Finland's growing nationalistic movement, one which led to Finnish becoming an official language in 1892 along with Swedish (the official language of the intelligentsia ever since Sweden's occupation of the country in the early fourteenth century).

11 Salmenhaara (1997) discusses the criticism levelled against Merikanto, Pingoud and Raitio during the 1910s and 1920s. 
during which nationalistic pride was running deep, also played a significant role in the difficulty these composers had in getting their works accepted. For instance, as a conscious opponent of nationalistic music, Pingoud may be the sole Finnish composer of note during this time whose music contains no reference to folk music or the Kalevala. Certainly his position was not made any easier by the numerous polemical essays and newspaper articles in which he stated that folk or nationalistically influenced music were the most infantile types of art music. $^{12}$

Now that we are able to distance ourselves from the entangled political associations of the time, it would be pertinent to examine to what degree foreign composers such as Scriabin and Stravinsky influenced the novel harmonies and formal designs found in Finnish music written during the 1910s and 1920s. For instance, while it is frequently acknowledged that the music by these two Russians influenced Klami, Merikanto, Pingoud and Raitio, any discussion about this subject has unfortunately been highly circumscribed-for Scriabin, the comments have centred upon the similarity of orchestral colours; for Stravinsky, almost exclusively on the rhythmic features of his early ballets. ${ }^{13}$

Clearly such discourse is incomplete: these four composers acknowledged that they heard Scriabin's and Stravinsky's music on numerous occasions, and it is doubtful that they would not have tried to implement in their own work the harmonic innovations drawn from music they considered represented vital contributions to contemporary art. Further, we must remember that during the 1910s Russia, with its geographic proximity, played a crucial position in introducing Finnish composers to foreign influences, which would naturally have included the progressive music written by its own composers. ${ }^{14} \mathrm{An}$ important factor here is the role played by the prominent Finnish conductor Robert Kajanus (1856-1933), leader of the Helsinki Philharmonic-Finland's only professional orchestra during the 1910s and 1920s. An avowed devotee of Sibelius (his recordings of the symphonies and symphonic poems are among the most essential interpretations of these pieces ever recorded), ${ }^{15}$ Kajanus frequently conducted in Russia and not only introduced Russian audiences to Finnish music (notably, Sibelius), but also brought contemporary Russian music to Finland. ${ }^{16}$ For instance, as Vainio $(1997,173)$ notes, Kajanus never once programmed a work by Béla Bartók, Alban Berg, Serge Prokofiev or Anton Webern (the only work by Arnold Schoenberg that he programmed was an orchestral transcription of Verklärte Nacht); however, he frequently performed Scriabin's latter two symphonies and two symphonic poems in Helsinki.

12 Pingoud (1995) contains a representative collection of these writings.

13 Korhonen (2003) and Salmenhaara (1997) are representative of such writings.

14 Consider, for instance, the case of Debussy. Petrova (2001) has shown that there were a far greater number of documented performances of Debussy's orchestral music in St. Petersburg compared with Helsinki between 1901 and 1920.

15 Layton (2001) contains a survey of the major conductors who have recorded Sibelius's music (the focus is on the symphonies and symphonic poems). In particular, he discusses the role Kajanus's recordings have had for subsequent interpreters of these works.

16 Kniazeva (2003) comments upon Kajanus's concerts in St. Petersburg during the 1910s and 1920 s, while Vainio (2002) discusses the role Kajanus played in introducing contemporary music to Finnish audiences. 
In short, rectification of this serious gap of scholarship is long overdue, for many younger Finnish composers considered the music of Stravinsky and Scriabin (along with that of Debussy and Ravel) to be the future direction of art music. Obviously, discussion of the multifarious, rich features of even one composer's style would extend far beyond the scope of this paper. Thus, in order to keep the length manageable, an illustration of musical influence will be centred upon one topic: namely, how the octatonic collection (a prominent harmonic feature in Scriabin's and Stravinsky's music) became a central aspect of three celebrated orchestral works-Klami's 1935 "The Creation of the Earth" (movement one from his five-movement Kalevala Suite), Movement One from Merikanto's 1924 Ten Pieces for Orchestra, and Raitio's 1921 Fantasia estatica. This is not to say that the octatonic collection is the only harmonic resource or stylistic attribute by Scriabin and Stravinsky that these composers appropriated in their respective music, nor that these three works are not the only compositions in which one can find the octatonic collection used. However, this harmonic collection is utilized in interesting and creative ways in these three works and, thus, they represent important exemplars of these composers' compositional technique and musical thought. Further, these are not minor or marginal compositions; rather, they rank as among the most popular, successful and representative works from each composer's early mature period. Finally, all three works are readily available on commercial recordings (Klami 1996; Merikanto 1996; Raitio 1992).

\section{TERMINOLOGY AND CONCEPTS}

The use of the octatonic collection has been identified as early as the mid-nineteenth century in some works by Mikhail Glinka and Franz Liszt, ${ }^{17}$ although Nikolai Rimsky-Korsakov is usually acknowledged as the first to actively utilize it in his music (he referred to the collection as the "whole step - half step scale"). ${ }^{18}$ However, during the past twenty years a growing body of scholarship has demonstrated just how pervasively the octatonic collection was used by late-nineteenth and early twentieth-century composers. ${ }^{19}$ Nevertheless, because the collection was so extensively utilized by Bartók, Scriabin and Stravinsky, it remains primarily associated with these three today. ${ }^{20}$ Richard Taruskin (1996) reminds us, though, that in order to truly understand the revolutionary use of the octatonic collection in Stravinsky's early ballets and Scriabin's later works, and

17 See chapter 5 of Maes (1996) for discussion on early use of the octatonic collection by these two composers.

18 Volume one of Taruskin (1996) discusses the use of the octatonic collection in Russian music prior to Stravinsky.

19 Forte (1987) examines the octatonic collection in the music of Liszt; Forte (1990) studies the collection in Mussorgsky; and McFarland (2000) and Parks (1983) discuss Debussy's use of the collection.

20 Antokoletz (1984) studies the role of the octatonic collection in the music of Bartók; Taruskin (1996) and van den Toorn (1983) examine the collection in Stravinsky; and Baker (1986), Taruskin (1997) and Perle (1984) discuss Scriabin's use of the collection. However, for a contrary opinion towards the somewhat accepted priority of octatonic collections in Stravinsky's music see Tymoczko (2002). 
why such compositions served as major influences for twentieth-century composers, it is important to differentiate between: (1) early "accidental" appearances of the collection (for instance, a soprano line that articulates the collection during a series of successive diminished seventh chords in a cadenza passage by Chopin or Liszt); (2) its use by Debussy, Ravel, Rimsky-Korsakov (Stravinsky's teacher) and Strauss (to cite four composers) as foreground melodic and harmonic material; and (3) occasions when composers such as Bartók, Scriabin and Stravinsky utilize the collection as a fundamental element of the background structure. Speaking about the revolutionary use of the octatonic collection in the 1911 ballet Petroushka, and its influence upon early twentieth-century composers, Taruskin $(1996,737)$ writes that

The octatonic collection is thus raised structurally to the level of a "key" in ordinary parlance, governing a hierarchy of pitches and functioning as a tonal center. It provides not only a referential vocabulary of pitch classes, but also a set of stable structural functions. Hence departures from it and returns to it-on various levels, from that of local "chromaticism" to that of "modulation"-are possible without compromising its referential integrity. The octatonic complex is in fact a much more stable referent within "Chez Pétrouchka" than any of the transient diatonic tonalities with which it interacts as the piece unfolds. The composition is thus a significant one within Stravinsky's stylistic evolution, different not merely in degree but also in kind from its precursors.

The octatonic collection contains eight pitches in a characteristic ordering which alternates between whole and half steps. ${ }^{21}$ Example 1 illustrates its three possible transpositions, labelled $\mathrm{OCT}_{0,1}, \mathrm{OCT}_{1,2}$ and $\mathrm{OCT}_{2,3 .}{ }^{22}$ Although there are several different ways to conceptualize the collection, perhaps the easiest is to hear it as two fully diminished $7^{\text {th }}$ chords placed a semitone apart. ${ }^{23}$

One challenge the analyst faces with works that utilize the octatonic collection is that it is rarely used in isolation but, rather, in conjunction with other harmonic

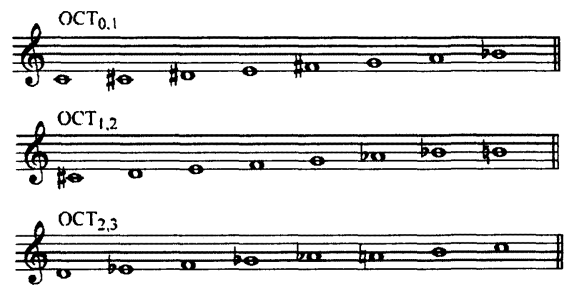

Example 1. Three transpositions of the octatonic collection

21 The first systematic discussion of the octatonic collection appears in Messiaen (1942), where he refers to the octatonic collection as one representative of his second mode of limited transposition.

22 This labelling system is derived from pitch-class set theory nomenclature, in which all pitches $\mathrm{C}$ are represented by the integer 0 , all pitches $C$-sharp/D-flat are represented by the integer 1 , all pitches $\mathrm{D}$ are represented by the integer 2, etc.; the specific taxonomy is adopted from Perle (1990).

23 As a side point of interest, jazz musicians frequently refer to the octatonic collection as the diminished scale. 
material. The problem stems from the collection's symmetrical design: unlike a major or minor scale, whose asymmetrical design generates an a priori system of hierarchical pitch relationships, the symmetry of the octatonic collection forces the hierarchical relationships established within a composition to be self-referential. In short, because of this important limitation of the collection, it is unusual for it to be the sole harmonic resource of an extended composition. When it is utilized, composers usually associate it with other harmonic resources, an issue to be addressed later in this article. Even in short works, pitches foreign to the collection are used in much the same way as chromatic notes are incorporated into tonal compositions. As an illustration, consider Example 2, the first half of Scriabin's short piano prelude Op. 74/3. Virtually every pitch of the composition is derived from the $\mathrm{OCT}_{0,1}$ collection. There are a few exceptions, illustrated by the circled pitches. Notice, in particular, Scriabin's special treatment of these circled pitches: in each instance, they are weak-beat passing pitches between two pitch elements from this particular octatonic collection. In sum, there is a direct comparison between the treatment of these foreign pitches in an octatonic environment and the weak-beat passing motion of second-species Fuxian counterpoint: in both instances, a dissonant element is utilized as passing motion between elements that are consonant with the particular collection in use.
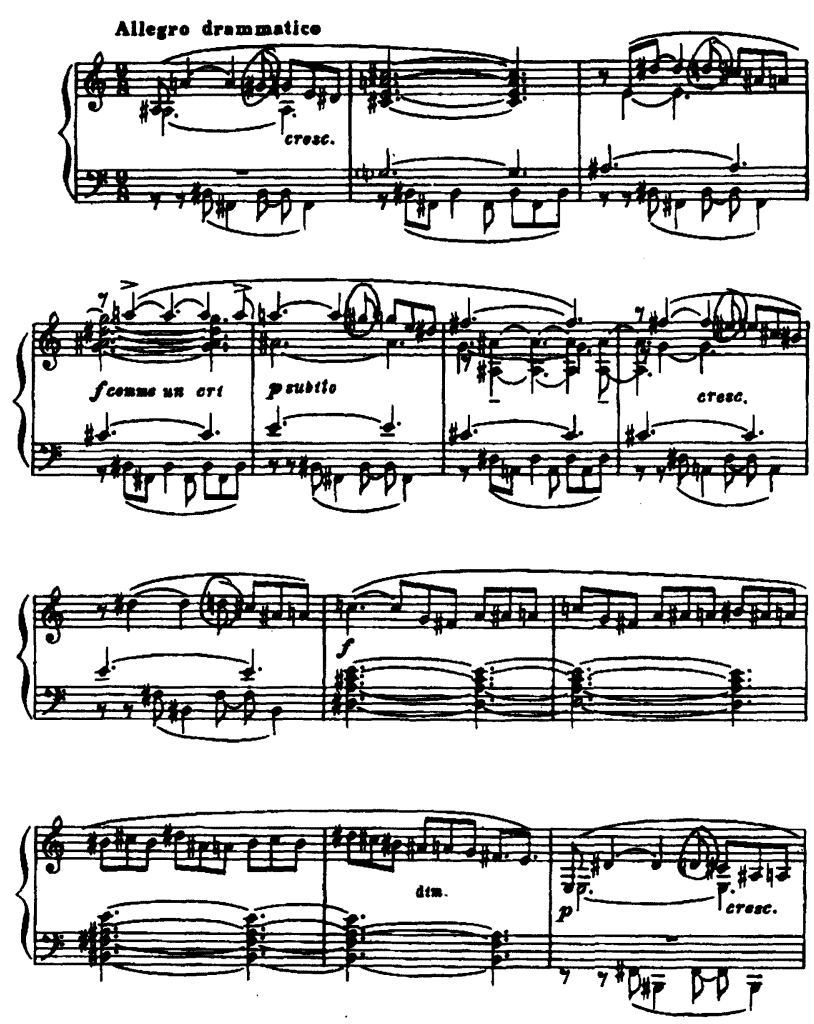

Example 2. Alexander Scriabin, Prelude, Op. 74/3, mm. 1-13 


\section{THREE ILLUSTRATIONS}

An analogous, albeit more complex example, similar to the Scriabin piece appears during the opening seven measures of Klami's "The Creation of the Earth," seen in Example 3. The passage is representative of the type of texture and rhythmic activity that appear throughout the opening section of the tripartite seven-minute first movement $(\mathrm{mm} .1-44)$. Of note is the nearly exclusive use of the $\mathrm{OCT}_{1,2}$ collection in the passage. The sole pitch outside of the collection is the F-sharp, played by the woodwinds and the first violins. However, unlike the weak beat passing pitch that was pointed out in the Scriabin piece, here the foreign element is placed on a strong beat in its role as accented passing motion to $\mathrm{G}$.

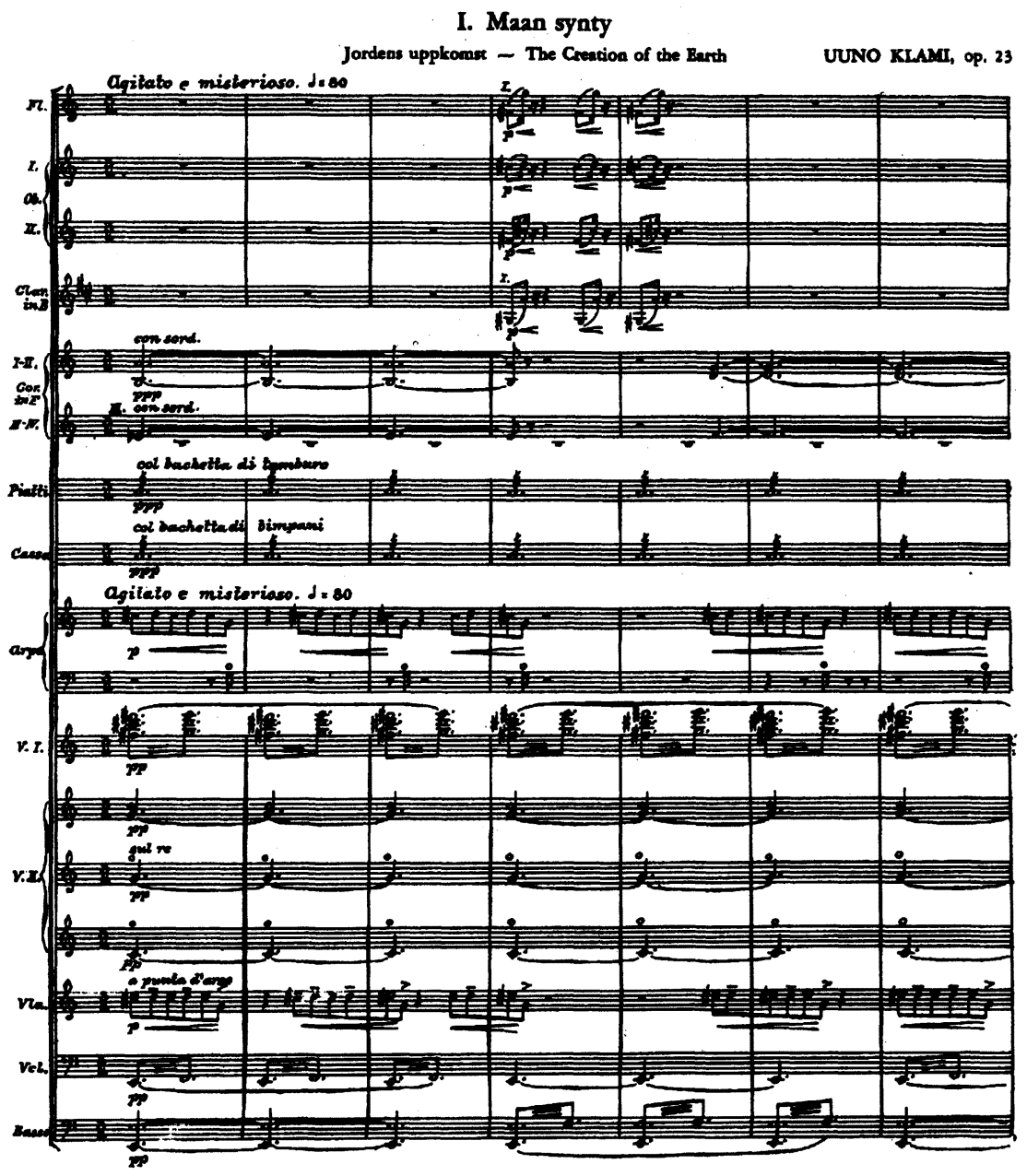

Example 3. Uuno Klami, Kalevala Suite, "The Creation of the Earth," mm. 1-7.

Copyright held by Fennica Gehrman Oy, Helsinki. Reprinted by permission. 
Example 4 presents another passage from Klami's work, the opening measures from the rhythmically aggressive second section. ${ }^{24}$ Like the opening portion of the piece, virtually the entire passage is derived from the $\mathrm{OCT}_{1,2}$ collection; however, the F-sharp now functions as a weak-beat passing dissonance.

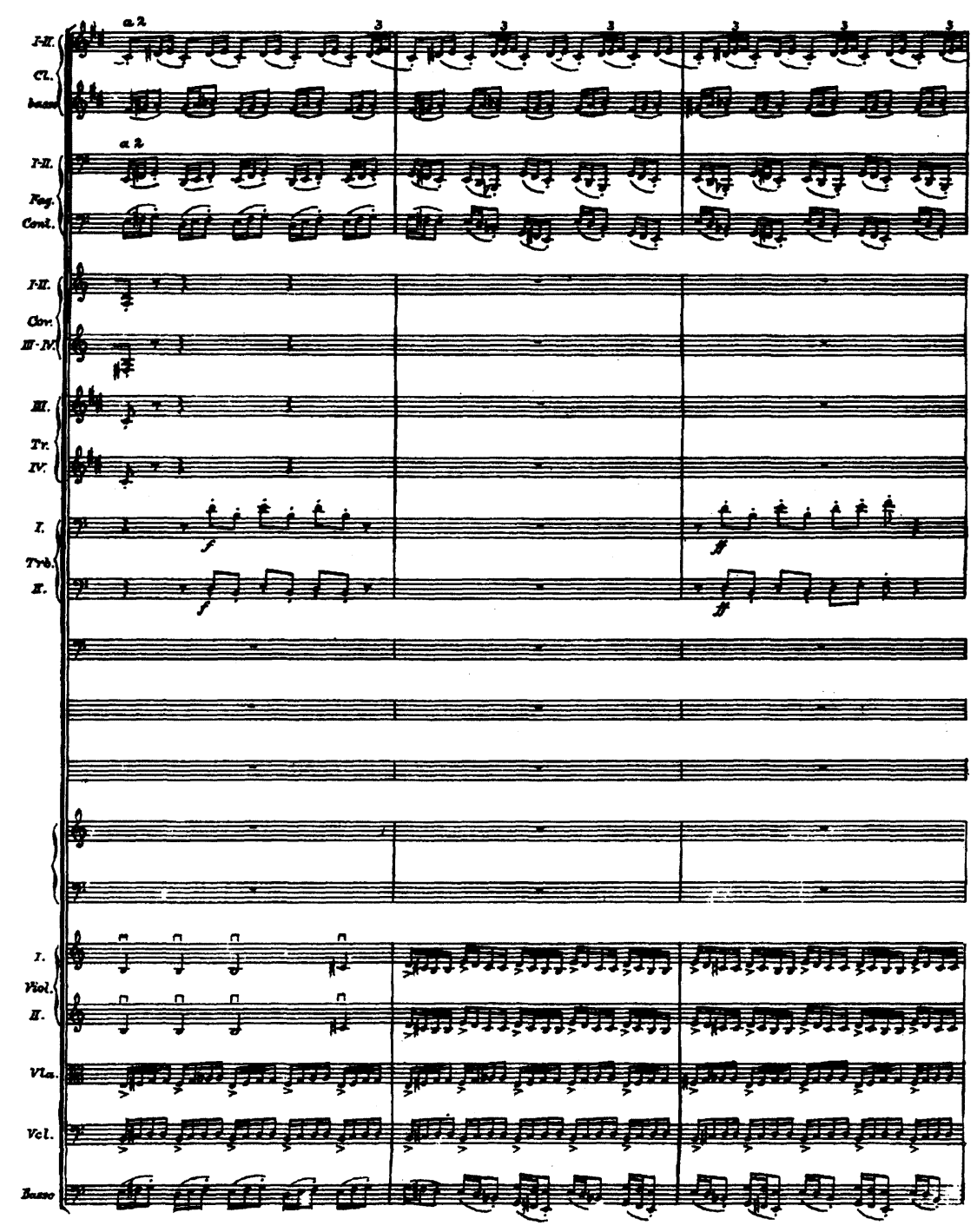

Example 4. Uuno Klami, Kalevala Suite, “The Creation of the Earth,” mm. 76-78. Copyright held by Fennica Gehrman Oy, Helsinki. Reprinted by permission.

24 The section's energetic rhythmic material, reminiscent of Stravinsky's Le Sacre du printemps has inspired critics to label the Kalevala Suite as the Finnish Sacre (Korhonen 2003, 66). 
The first movement of Merikanto's Ten Pieces for Orchestra provides a more complex illustration of how dissonance can be utilized within an octatonic environment. The piece is based on a ternary design: part $\mathrm{A}, \mathrm{mm}$. 1-8; the contrasting part $\mathrm{B}, \mathrm{mm}$. 18-21 (a transition from mm. 9-17 links these two parts); and a recapitulation of part A, in mm. 22-37).

Of interest is how different transpositions of the octatonic collections correlate with this design. For instance, Example 5 contains the opening four measures of the movement. Every pitch except the A-natural played by the oboe in $\mathrm{m} .3$ is derived from an $\mathrm{OCT}_{1,2}$ collection. Although this pitch is initially relegated to an inner voice, it becomes much more prominent throughout the movement. In fact, an attractive feature of this movement is not only the connection between the formal design and octatonic collection transpositions, but also the corre-

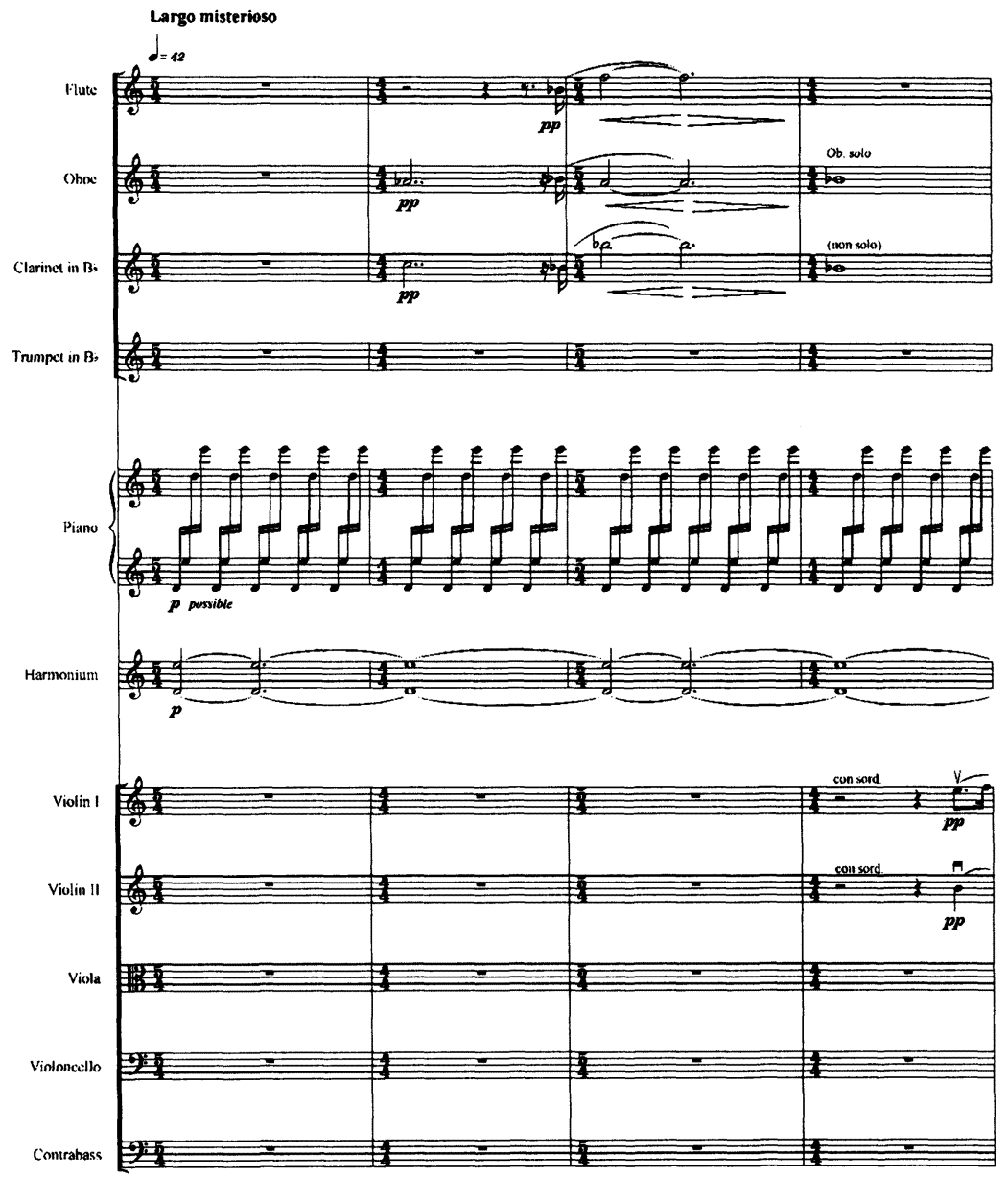

Example 5. Aarre Merikanto, Ten Pieces for Orchestra, Mov. 1, mm. 1-4 Copyright held by Fennica Gehrman Oy, Helsinki. Reprinted by permission. 
sponding relationship with the changing role of this pitch. For instance, during the transition from part $A$ to part $B$ this dissonance changes from a less obtrusive inner voice (i.e., of the trichord in $\mathrm{m}$. 3 ) to a prominent appoggiatura figure from the violins' melodic line (Example 6 illustrates this figure, as found in $\mathrm{mm}$. 13-14). In the contrasting part $\mathrm{B}$, the $\mathrm{A}$ is now consonant with the $\mathrm{OCT}_{0,1}$ collection that forms the basis of the harmonic material. Note, however, that the $\mathrm{D}$-originally an element of the D-E ostinato played by the piano and harmonium and which is consonant with the $\mathrm{OCT}_{1,2}$ collection-is now dissonant with the $\mathrm{OCT}_{0,1}$ transposition. Example 7 illustrates the role reversal of these pitches in $\mathrm{mm} .19-21$. Here the A is played by both the oboe and trumpet, while the $\mathrm{D}$ (the highest pitch in the passage) is heard in imitative fashion-first by the trumpet, followed by the oboe. With the recapitulation of Part A in $\mathrm{m} .22$ (in which the $\mathrm{ocT}_{1,2}$ collection once again forms the basis of the harmonic material), the A returns to its former role as a dissonance. Initially, it appears as an appoggiatura resolving to a G-sharp as part of a two-trichord ostinato (the opening measures of the recapitulation, mm. 22-23, are illustrated in Example 8). In fact, the second trichord also contains an A played by the cellos: its position as an inner voice, combined with the perfect fifth the pitch forms with the lower cello note D, substantially reduces the "bite" of this dissonance. However, this ostinato gradually diminishes in prominence; as the movement draws to a close, a passage comparable in texture and instrumentation to the opening measures is recapitulated, and the pitch A returns to a relatively unobtrusive middle voice, as witnessed in the final harmony of the work.

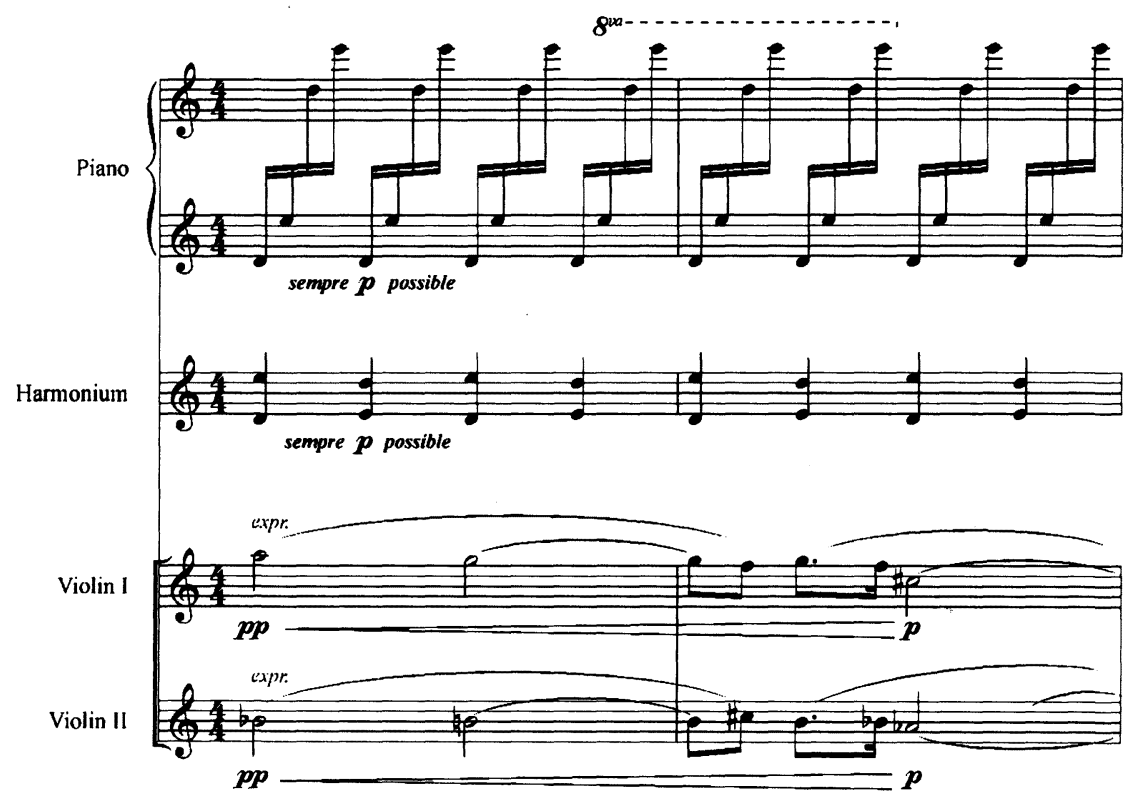

Example 6. Aarre Merikanto, Ten Pieces for Orchestra, Mov. 1, mm. 13-14 Copyright held by Fennica Gehrman Oy, Helsinki. Reprinted by permission. 


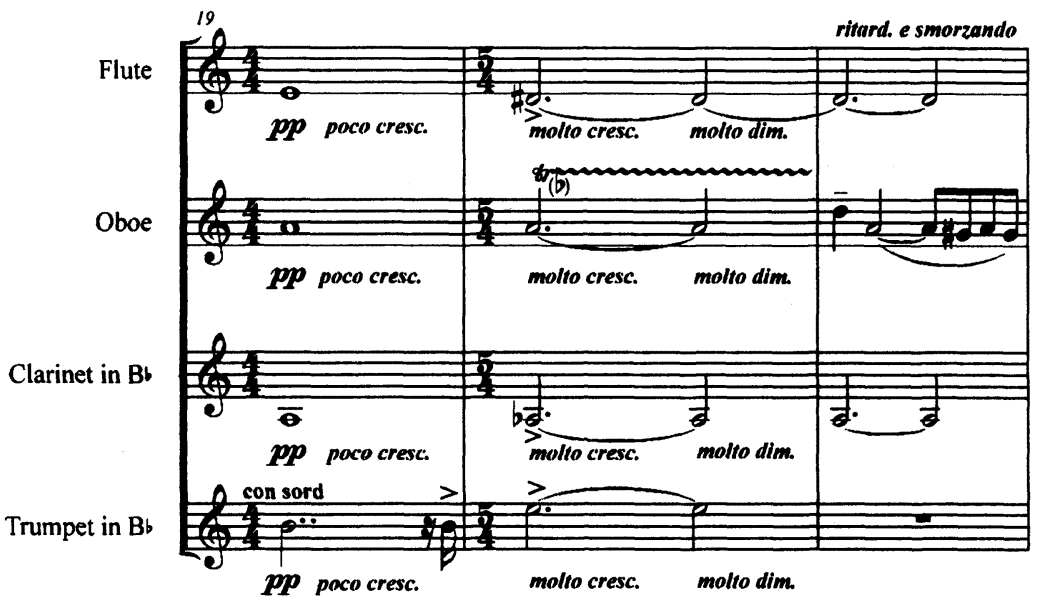

Example 7. Aarre Merikanto, Ten Pieces for Orchestra, Mov. 1, mm. 19-21 Copyright held by Fennica Gehrman Oy, Helsinki. Reprinted by permission.

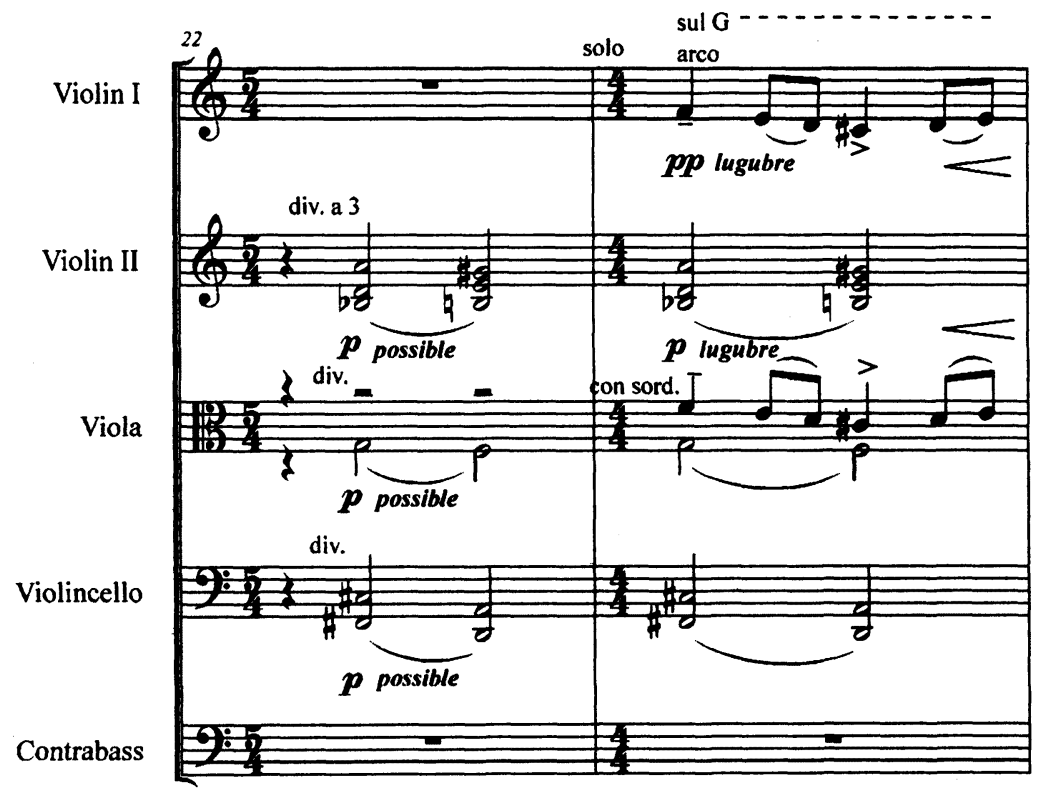

Example 8. Aarre Merikanto, Ten Pieces for Orchestra, Mov. 1, mm. 22-23 Copyright held by Fennica Gehrman Oy, Helsinki. Reprinted by permission. 
The discussion thus far has centred upon either one octatonic collection or a series of successive transpositions of the collection. However, different transpositions of the octatonic collection may appear simultaneously. The opening measures of Raitio's tone poem Fantasia estatica contains an interesting simultaneous projection of two collections: $\mathrm{OCT}_{2,3}$ in the lower strings and $\mathrm{OCT}_{0,1}$ in the horns (Example 9 contains all the pitch material, but eliminates the many empty staves in these measures). Of note is how each collection articulates a different musical gesture and a distinct musical register (as with the earlier examples, the occasional pitches outside each respective collection are used as either passing or neighbour note motion).

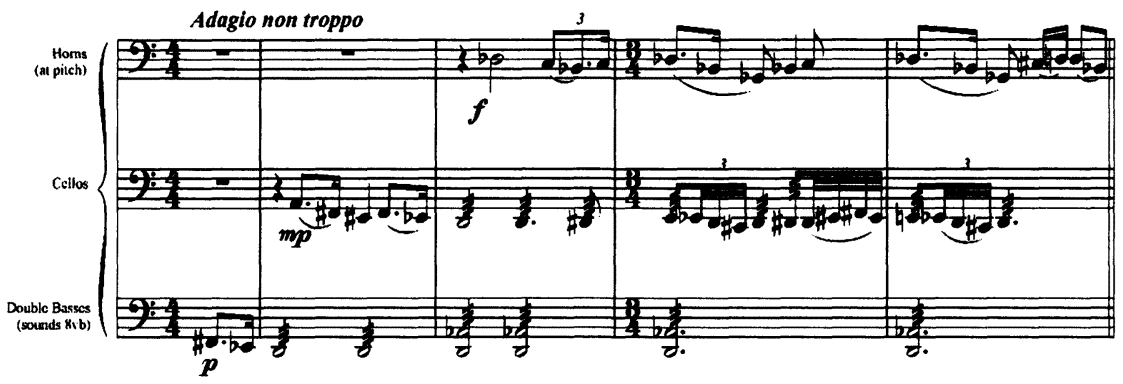

Example 9. Väinö Raitio, Fantasia estatica, mm. 1-4 (simplified version).

Copyright held by Fennica Gehrman Oy, Helsinki. Reprinted by permission.

For a more texturally complex illustration of simultaneous presentations of two different octatonic collections, let us briefly return to Merikanto's work-specifically, the transition of mm. 9-17. Here, the pitch material of the winds and brass is derived from the $\mathrm{OCT}_{0,1}$ collection (perhaps as a harbinger of the harmonic material that will dominate Part B mm. 18-21), while the piano, harmonium and strings continue to utilize pitch material from the $\mathrm{OCT}_{1,2}$ collection (the transposition that predominated in Part A, mm.1-8).

A large number of the themes, prominently recurring motives and vital harmonic material in Fantasia estatica are generated from the three transpositions of the octatonic collection. However, the correspondence between divergent layers of sonic activity and the simultaneous interaction between two transpositions of the octatonic collection identified in the opening measures recurs at two key points in the work, expressing important formal areas of the work's ternary design. For instance, the contrasting part $\mathrm{B}$ begins at $\mathrm{m}$. 51 with a short Piu lento section of four measures. The $\mathrm{OCT}_{2,3}$ collection is used to engender two motives-played by the clarinets and bassoon and the flutes and celesta respectively. Simultaneously, however, the oboe plays an abridged version of the opening lower strings gesture, using the $\mathrm{OCT}_{0,1}$ 
collection. The recapitulation of Part A begins with the orchestral tutti at $\mathrm{m}$. 85. Amidst the chromatic scalar activity played by the woodwinds and strings, two motives appear, played fortissimo: one by the horns, based from the $\mathrm{OCT}_{0,1}$ collection; the other by the trumpets, using the $\mathrm{OCT}_{2,3}$ collection.

At this juncture, it would be pertinent to identify a second harmony that features crucially in several works by Merikanto, Pingoud and Raitio-i.e., Scriabin's so-called "Prometheus chord," which plays such a prominent role in his celebrated tone poem Prometheus Op. 60. Example 10 presents the chord in its initial realization at the outset of the work. To the right, it is rearranged within an octave to illustrate a far more important characteristic of the chord-namely, that it is nothing more than a whole-tone collection with one note changed (in the present example, $\mathrm{F}$ is replaced with F-sharp).

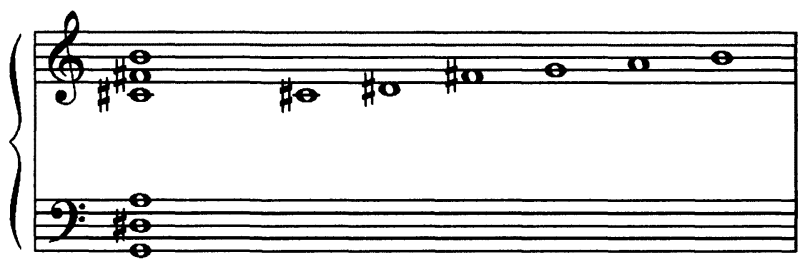

Example 10. Scriabin's "Prometheus" chord

An exhaustive study of how this chord was used by Finnish composers during the 1910s and 1920s (for instance, Merkikanto's Pan of 1924 or Pingoud's Le Prophète written in 1921) is the topic of another paper. For now, though, it is worth identifying the sonority's appearance in the second theme from part A of Fantasia estatica-largely because the passage contains an interesting association of the harmony with a series of transpositions of the octatonic collection. (Example 11 presents a skeletal reduction of the initial portion of the theme in mm. 40-47; the example eliminates octave doublings.) The trichord from the middle stave of each measure is not a sustained whole note, as is the case in the lower stave for the lower strings and brass, but rather represents the pitches arpeggiated by the upper strings, celesta and woodwinds in triplet-sixteenth rhythmic values. The theme is essentially a series of sequential statements of a motive, played by the trumpet and represented by the material in the uppermost stave. The dynamic level increases gradually with each successive element of the sequence, leading to the culminating final measure. The sonorities, as well as virtually all the embellishing foreground material, are derived from different octatonic collections, identified below. Note, however, that the series of trumpet pitches on each downbeat is A-sharp, C, D, E, F, G-sharp. The transposition levels of the sequence are not arbitrary but, rather, a linear rendering of the Prometheus chord. 


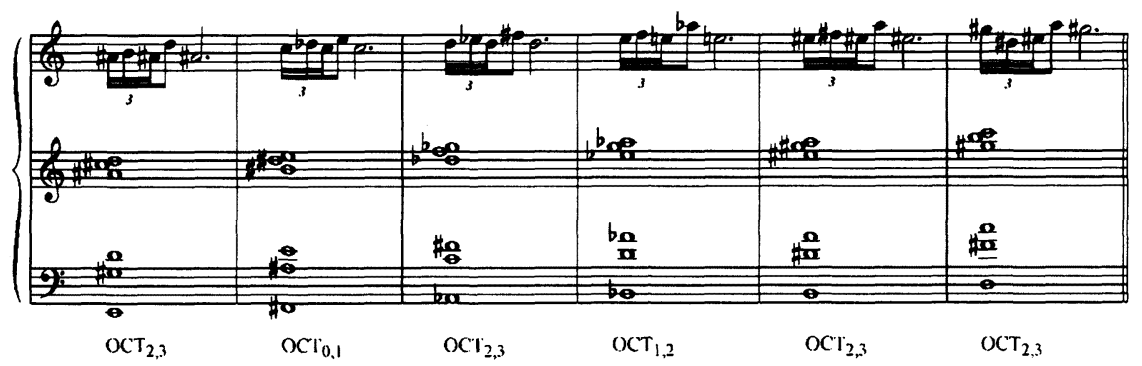

Example 11. Väinö Raitio, Fantasia estatica, mm. 40-47 (simplified version)

When dealing with pieces of even a greater dimension, the analytical problems become more complex, mainly because divergent resources are utilized to avoid harmonic monotony. A commonly cited example of this combination of materials is found with Stravinsky's music and, specifically, its integration of diatonic, modal and octatonic collections. Taruskin (1996, 737-59) has outlined how octatonic collections represent an essential feature of the underlying structure of second tableau of Petroushka, as well as how the meshing of octatonic, modal and diatonic collections forges its underlying formal design.

It is reasonably safe to assert that a de facto feature of an extended composition utilizing octatonic material is its coordination with other harmonic resources. Consequently, an obvious organising principle of such works would be the exploitation of this dichotomous harmonic material to underline the composition's formal design. As an illustration of this use of diatonic modes and octatonic collections, consider Klami's "The Creation of the Earth." The texture outlined in Example 3 extends for forty-four measures; tedium is averted through the carefully constructed dialogue between the harp/viola three-note motive and the dissonant $\mathrm{F}$-sharp to $\mathrm{G}$ ascending minor-ninth gesture. In fact, the first "melody" to appear in the piece begins in m. 25; shown in Example 12, this folk-like melody is constructed from a B-flat natural minor scale and is prominently featured for the remainder of section one (mm. 25-44). The B-flat centricity is significant, for it presents a foil to the " $E$ " focus played by the low registered instruments. In addition, the harmonies in this section, like those of the opening twenty-four measures, are generated from an $\mathrm{OCT}_{1,2}$ collection.

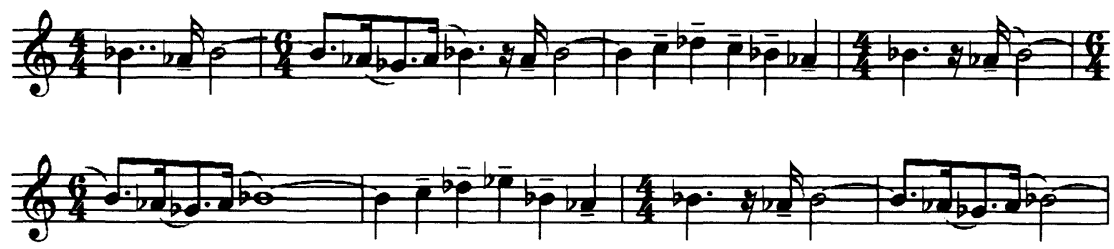

Example 12. Melody from Uuno Klami, Kalevala Suite, "The Creation of the Earth," mm. 25-33 
Comparable tonal conflicts appear throughout Klami's piece, defining each section and transition. For instance, the transition to section two $(\mathrm{mm}$. 45-72) oscillates between the $\mathrm{OCT}_{0,1}$ and $\mathrm{OCT}_{1,2}$ collections. While the pitch E continues to dominate the bass register, a variant of the folk melody is now stated in F minor. In section two, a further modification of the folk-styled melody appears in F-sharp minor, played by the woodwinds. The melody is supported by $\mathrm{OCT}_{1,2}$ material; $\mathrm{E}$ continues to be the most frequently articulated pitch by the bass instruments. Finally, in section three the folk melody, rooted in A natural minor, is played in full splendour by the horns. $\mathrm{OCT}_{1,2}$ remains the chief octatonic collection; although the prominence of $E$ as a bass pitch remains, C-sharp and B are also occasionally used. The movement ends with a unison $\mathrm{E}$, confirming the importance of this tonal focus.

\section{CONCLUSION}

That a generation of post-World War I Finnish composers would look to foreign sources as they attempted to move beyond the accepted norms of National Romanticism, a style highly influenced by Sibelius, will come as little surprise to those acquainted with the music of the early twentieth-century. However, the significance of Scriabin's and Stravinsky's music during this critical time in Finland's history is particularly extraordinary. We have seen that the octatonic collection, an acknowledged attribute of both Russians' music, is not only used as an important harmonic resource, but also functions (as in works like Stravinsky's Petroushka and Scriabin's Op. 74 piano preludes) to demarcate the formal designs of the major orchestral compositions we have examined. This is not to say, however, that this particular harmonic collection is the sole attribute of Scriabin's and Stravinsky's music these Finnish composers utilized. For instance, as was noted earlier, Scriabin's celebrated "Prometheus" chord was also employed to varying degrees (Pingoud exploited this harmonic device more than the other three). Further, other compositional attributes of Scriabin's and Stravinsky's music were exploited; elsewhere, I have discussed how characteristic aspects of rhythm and form in Stravinsky's Russian-period ballets are used in a number of Klami's early works, including his Kalevala Suite and 1927 Karelian Rhapsody (Jurkowski 2003). Finally, as Kimmo Korhonen (1995, 40-62) suggests, the evocative titles of many pieces during the 1910s and 1920s (Moonlight on Jupiter and Antigone by Raitio and Flambeaux éteints and Le chant de l'espace by Pingoud) are indicative of a fascination with the mystical side of Scriabin's persona and in particular, his interest in theosophy that informed his post1905 compositions. ${ }^{25}$ Unfortunately no inquiry has as yet examined the exact extent to which Scriabin's philosophical leanings may have influenced these composers.

25 Although he does not address musical composition, Pekka Ervast (1999, xii-xiii and xxxi-xxxii) has discussed how theosophy influenced a number of Finnish writers and poets during the 1910 s. 
In short, there are several areas of research that need to be addressed before we have a broad and secure understanding of the changes that first appeared in Finnish music during the late 1910s, and which have continued throughout the last century. The good news is that these topics of historical inquiry are beginning to attract the attention of current scholars (witness, for instance, the two-day symposia held in April 2003 in Helsinki and in October 2004 in St. Petersburg, both devoted to the very topic of Finnish/Russian musical relations). ${ }^{26}$ In time, we will be in a position to establish a compelling historiography of the vital relationship between Russian and Finnish music during the early twentieth century.

\section{REFERENCE LIST}

Anderson, Julian. 2004. "Sibelius and contemporary music." In The Cambridge Companion to Sibelius, Daniel M. Grimley, ed. Cambridge: Cambridge University Press. 196-216.

Antokoletz, Elliott. 1984. The Music of Béla Bartók: A Study of Tonality and Progression in Twentieth-Century Music. Berkeley: University of California Press.

Baker, James. 1986. The Music of Alexander Scriabin. New Haven: Yale University Press.

Englund, Einar. 1996. I skuggan av Sibelius [In the Shadow of Sibelius]. Helsingfors: Söderström.

Ervast, Pekka. 1999. The Key to the Kalevala [Kalevalan Avain, 1916]. Translated by Tapio Joensuu. Nevada City: Blue Dolphin Publishing.

Forte, Allen. 1987. "Liszt's Experimental Music and Music of the Early Twentieth Century." $19^{\text {th }}$-Century Music 10: 209-28.

. 1990. "Musorgsky as Modernist: The Phantasmic Episode in Boris Godunov." Music Analysis 9: 3-45.

. 1991. "Debussy and the Octatonic." Music Analysis 10/1-2: 125-69.

Gray, Laura. 1996. "Sibelius and England." In The Sibelius Companion, Glenda Dawn Goss, ed. Westport: Greenwood Press. 281-95.

Henshall, Dalwyn James. 1984. "A survey of Finnish Music 1900-1984." Master's Thesis, The Royal Welsh College of Music and Drama.

Hepokoski, James. 1993. Sibelius: Symphony No. 5. Cambridge: Cambridge University Press.

Howell, Tim. 1989. Jean Sibelius: Progressive Techniques in the Symphonies and Tone Poems. New York: Garland.

Jackson, Timothy L. and Veijo Murtomäki, eds. 2001. Sibelius Studies. Cambridge: Cambridge University Press.

Jones, W. Glyn, ed. 1985. “Kalevala” 1835-1985: The National Epic of Finland. Helsinki: Helsinki University Library.

26 The conferences entitled "Finnish-Russian Musical Relations" were held on 7-8 April 2003 in Helsinki and 4-6 October 2004 in St. Petersburg. They featured scholars from Russia and Finland, as well as several other European countries, Canada and the United States. 
Jurkowski, Edward. 2003. “Aspects of Stravinsky's Influences on the Early Music of Uuno Klami." In Symposion Uuno Klami 1900-2000, Helena Tyrväinen, ed. Helsinki: Sibelius Academy. 143-55.

Klami, Uuno. 1996. Uuno Klami: Meet the Composer. Various conductors and orchestras. Compact disc, Finlandia CD4509-99968-2.

Kniazeva, Janna. 2003. "The Kajanus Brothers in Saint Petersburg." Paper delivered at the "Finnish-Russian Musical Relations" symposium. 7-8 April, 2003.

Korhonen, Kimmo. 1995. Finnish Orchestral Music I. Helsinki: Finnish Music Information Centre.

2003. Inventing Finnish Music. Helsinki: Finnish Music Information Centre.

Layton, Robert. 2001. "From Kajanus to Karajan: Sibelius of record." In Sibelius Studies, Timothy L. Jackson and Veijo Murtomäki, eds. Cambridge: Cambridge University Press. 14-34.

Maes, Francis. 1996. A History of Russian Music. Berkeley: University of California Press.

McFarland, Mark. 2000. "Debussy and Stravinsky: Another look into their Musical Relationship." Cahiers Debussy 24: 79-112.

Mead, W. R. 1968. Finland. London: Ernest Benn Ltd.

Merikanto, Aarre. 1996. Aarre Merikanto: Meet the Composer. Various conductors and orchestras. Compact disc, Finlandia CD4509-99970-2.

Messiaen, Olivier. 1942. Technique de mon langage musical. Paris: Alphonse Leduc.

Murtomäki, Veijo. 1993. Symphonic Unity: The Development of Formal Thinking in the Symphonies of Sibelius. Helsinki: University of Helsinki.

Nummi, Seppo and Timo Mäkinen. 1985. Musica Fennica. Helsinki: Otava.

Oramo, Ilkka. 2004. "Sub umbra Sibelit: Sibelius and his successors." In The Cambridge Companion to Sibelius, Daniel M. Grimley, ed. Cambridge: Cambridge University Press. 157-68.

Parks, Richard. 1983. The Music of Claude Debussy. New Haven: Yale University Press.

Perle, George. 1984. “Scriabin's Self Analyses.” Music Analysis 3/2: 101-22. . 1990. The Listening Composer. Berkeley: University of California Press.

Pingoud, Ernest. Valittuja kirjoituksia musiikista ja kirjallisuudesta. Kalevi Aho, ed. Helsinki: Gaudeamus.

Raitio, Väinö. 1992. Orchestral Works. Finnish Radio Symphony Orchestra. Jukka-Pekka Saraste, conductor. Compact disc, Ondine ODE 790-92.

Salmenhaara, Erkki. 1997. "Finnish Music in the 20s and 30s: Internationalism vs. Nationalism." In Music and Nationalism in 20th-Century Great Britain and Finland, Tomi Mäkelä, ed. Hamburg: von Bockel Verlag.

Singleton, Fred. 1989. A Short History of Finland. Cambridge: Cambridge University Press.

Solsten, Eric and Sandra Meditz, eds. 1990. Finland: A Country Study. Washington DC.: Library of Congress Publication. 
Szendy, Peter. 1993. "Interview with Magnus Lindberg." In Magnus Lindberg, Risto Nieminen, ed. Helsinki: Finnish Music Information Centre. 7-25. Taruskin, Richard. 1996. Stravinsky and the Russian Traditions: A Biography of the Works Through Mavra. Berkeley: University of California Press. . 1997. "Scriabin and the Superhuman: A Millennial Essay." In Defining Russia Musically, Richard Taruskin. Princeton: Princeton University Press. 308-59.

Tymoczko, Dmitri. 2002. "Stravinsky and the Octatonic: A Reconsideration." Music Theory Spectrum 24/1: 68-102.

Tyrväinen, Helena. 2000. "Les origines de la réception de Debussy en Finlande (1901-1933)." Cahiers Debussy 24: 3-23.

Vainio, Matti. 1997. "How Modernism came to Finland? An Exposition of the History of Ideas." In Music and Nationalism in 20th-Century Great Britain and Finland, Tomi Mäkelä, ed. Hamburg: von Bockel Verlag. .2002. Nouskaa aatteet!: Robert Kajanus: elämä ja taide. WSOY: Porvoo. van den Toorn, Pieter C. 1983. The Music of Igor Stravinsky. New Haven: Yale University Press.

\begin{abstract}
This article examines a significant shift in musical style and compositional technique that occurred in Finland during the 1920s, a time during which the music of Jean Sibelius exerted a strong influence. Specifically, I discuss how the octatonic collection, a prominent feature in the music of the two early twentieth-century Russian modernists Igor Stravinsky and Alexander Scriabin, is incorporated as a fundamental harmonic resource in three celebrated orchestral works: Uuno Klami's 1935 "The Creation of the Earth" (movement one from his five-movement Kalevala Suite), movement one from Aarre Merikanto's 1924 Ten Pieces for Orchestra, and Väinö Raitio's 1921 tone poem Fantasia estatica.
\end{abstract}

\title{
RÉSUMÉ
}

Cet article met en évidence une évolution importante du style musical et des techniques de composition apparus en Finlande au cours des années 1920, période pendant laquelle la musique de Jean Sibelius avait une grande influence. Plus précisément, mon propos porte sur les collections de type octatonique - particulièrement présentes chez les deux modernistes russes du début du $\mathrm{XX}^{\mathrm{e}}$ siècle, Igor Stravinsky et Alexandre Scriabine - et leur intégration à titre de ressource harmonique fondamentale dans trois œuvres pour orchestre reconnues : " la Création de la Terre", premier mouvement des cinq composant la Suite Kalevala de Uuno Klami (1935), le premier mouvement des 10 Pièces pour Orchestre de Aarre Merikanto (1924) et le poème orchestral Fantasia estatica de Väinö Raitio (1921). 